\title{
Effect of following food regimen per eight constitution medicine on health outcomes: A German study
}

\author{
Changkeun $\mathrm{Kim}^{1 *}$, Dowon Kuon ${ }^{2}$, Myoungin Kim${ }^{3}$, Bo-Hyoung Jang ${ }^{4}$, Woojin Kim ${ }^{5}$ \\ Rampp T. ${ }^{6}$, Hyesuk Park $^{7}$ \\ ${ }^{1}$ CHA University School of Medicine, Chaum Life Center, Seoul, Republic of Korea \\ ${ }^{2}$ Jesun Constitution Clinic, Seoul, Republic of Korea \\ ${ }^{3}$ Mennonite College of Nursing, Illinois State University, Illinois, U.S.A. \\ ${ }^{4}$ Department of Preventive Medicine, College of Korean Medicine, Kyung Hee University, Seoul, Republic of Korea \\ ${ }^{5}$ Department of Physiology, College of Korean Medicine, Kyung Hee University, Seoul, Republic of Korea \\ ${ }^{6}$ Department of Integrative Medicine, Essen University Hospital, Essen, Germany \\ ${ }^{7}$ Department of Architecture, RWTH Aachen University, Aachen, Germany
}

Objectives: Eight Constitution Medicine (ECM) categorizes individuals into eight constitutions based on physiological differences in organ relations and recommends different diets for different constitutions. This study presents a preliminary analysis of the effect of following constitutional food regimens on quality of life and health outcomes for different constitutions.

Methods: This cross-sectional, comparative study used subjects recruited from Essen University Hospital Traditional Chinese Medicine Center in Germany. From a convenience sample of 243 Germans, those in the groups Hepatonia/Cholecystonia $(n=95)$ and Pulmotonia/Colonotonia $(n=26)$ were analyzed for health outcomes in relation to their dietary habits of either including or avoiding meat. Health outcomes were measured with SF-36, self-reported survey.

Results: The two groups had no significant differences in the health outcomes of SF-36. However, subjects in Hepatonia/Cholecystonia who had followed their dietary habit for more than 20 years had significantly better scores on general health, social functioning, mental health, emotional role functioning, and mental component scores than those in Pulmotonia/Colonotonia, regardless of their meat intake.

Conclusions: This study established initial groundwork for considering patients' constitutions when evaluating health outcomes and their relation to diet. Further studies are warranted on the effects of regulating food intake according to individual constitution.

$\overline{\text { Key Words }}$ : Eight Constitution Medicine (ECM), Meat, Vegetable, SF-36, Korean Medicine

\section{Introduction}

Although modern medical advances in antibiotics and vaccines have extended the average human life expectancy, illnesses such as chronic infectious disease, cardiovascular disease, cancer, and immunological diseases have become more prevalent than ever, and such challenges are likely to continue. Effectively addressing such medical challenges may require a change in the

\footnotetext{
- Received : 2 November 2020

- Revised : 25 November 2020

- Accepted : 30 November 2020

- Correspondence to : Changkeun Kim

CHA University School of Medicine, Chaum Life Center

22, 129-gil, Soelleung-ro, Kangnam-gu, Seoul, Republic of Korea

Tel : +82-10-3100-2979, Fax : +82-2-543-4936, Email : ecm1967@naver.com
} 
medical paradigm.

Constitutional medicine is a methodology for treating disease or promoting health by focusing on one's individuality rather than one's generality. Major attributes of constitutional medicine include diagnosis and treatment based on individual psychological and somatic personality. In Korea, "Sasang" medicine was established in 1894 by Dr. Lee Je- $\mathrm{Ma}^{1-2)}$ and further developed in 1965 as Eight Constitution Medicine (ECM) by Dr. Kuon Dowon, who recognized eight combinations of strength relations among the liver, gall bladder, heart, small intestine, pancreas, stomach, lung, large intestine, kidney, and urinary bladder ${ }^{3)}$. Dr. Kuon confirmed the factors in the formation of the eight constitutions through extensive clinical experience and studies ${ }^{4)}$, and he presented guidelines for diagnosing and treating disease according to the eight constitutions in $1974^{5}$. Since its introduction, ECM has been used in Korea for over 50 years of clinical experience in treating patients for diverse disorders ${ }^{6}$.

The core of the ECM is the idea that not all people are born equal in that organs making up the human body are not equally balanced in strength and power. Each constitution has organs that are stronger, some that are weaker, and some in between. The distinctions among constitutions can be seen in the arrangement of the middle organs. Different orders of organs for 8 constitutions are shown in Table 1 and further details about ECM can be found in the studies by Dr. Kuon ${ }^{3-5)}$. (Table 1.)

The ECM emphasizes that the most important

Table 1. Different orders of Zangs and Fus in 8 constitutions

\begin{tabular}{|c|c|}
\hline \multirow{2}{*}{ Constitution name } & Order of organic strength and weakness \\
\hline & Strongest organ $>$ strong organ $>$ intermediate organ $>$ weak organ $>$ weakest organ \\
\hline Pulmotonia & $\begin{array}{l}\mathrm{VII}(\mathrm{VIII})>\mathrm{V}(\mathrm{VI})>\mathrm{III}(\mathrm{IV})>\mathrm{IX}(\mathrm{X})>\mathrm{I}(\mathrm{II}) \mathrm{a} \\
\text { metal }>\text { earth }>\text { fire }>\text { water }>\text { wood }\end{array}$ \\
\hline Colonotonia & $\begin{array}{l}\mathrm{VIII}(\mathrm{VII})>\mathrm{X}(\mathrm{IX})>\mathrm{VI}(\mathrm{V})>\mathrm{IV}(\mathrm{III})>\mathrm{II}(\mathrm{I}) \\
\text { metal }>\text { water }>\text { earth }>\text { fire }>\text { wood }\end{array}$ \\
\hline Pancreotonia & $\begin{array}{l}\mathrm{V}(\mathrm{VI})>\mathrm{III}(\mathrm{IV})>\mathrm{I}(\mathrm{II})>\mathrm{VII}(\mathrm{VIII})>\mathrm{IX}(\mathrm{X}) \\
\text { earth }>\text { fire }>\text { wood }>\text { metal }>\text { water }\end{array}$ \\
\hline Gastrotonia & $\begin{array}{l}\mathrm{VI}(\mathrm{V})>\mathrm{VIII}(\mathrm{VII})>\mathrm{IV}(\mathrm{III})>\mathrm{II}(\mathrm{I})>\mathrm{X}(\mathrm{IX}) \\
\text { earth }>\text { metal }>\text { fire }>\text { wood }>\text { water }\end{array}$ \\
\hline Hepatonia & $\begin{array}{l}\mathrm{I}(\mathrm{II})>\mathrm{IX}(\mathrm{X})>\mathrm{III}(\mathrm{IV})>\mathrm{V}(\mathrm{VI})>\mathrm{VII}(\mathrm{VIII}) \\
\text { wood }>\text { water }>\text { fire }>\text { earth }>\text { metal }\end{array}$ \\
\hline Cholecystonia & $\begin{array}{l}\mathrm{II}(\mathrm{I})>\mathrm{IV}(\mathrm{III})>\mathrm{VI}(\mathrm{V})>\mathrm{X}(\mathrm{IX})>\mathrm{VIII}(\mathrm{VII}) \\
\text { wood }>\text { fire }>\text { earth }>\text { water }>\text { metal }\end{array}$ \\
\hline Renotonia & $\begin{array}{l}\mathrm{IX}(\mathrm{X})>\mathrm{VII}(\mathrm{VIII})>\mathrm{I}(\mathrm{II})>\mathrm{III}(\mathrm{IV})>\mathrm{V}(\mathrm{VI}) \\
\text { water }>\text { metal }>\text { wood }>\text { fire }>\text { earth }\end{array}$ \\
\hline Vesicotonia & $\begin{array}{l}\mathrm{X}(\mathrm{IX})>\mathrm{II}(\mathrm{I})>\mathrm{IV}(\mathrm{III})>\mathrm{VIII}(\mathrm{VII})>\mathrm{VI}(\mathrm{V}) \\
\text { water }>\text { wood }>\text { fire }>\text { metal }>\text { earth }\end{array}$ \\
\hline \multicolumn{2}{|c|}{$\begin{array}{l}\text { a; Following the notation in Kuon's thesis in 1974, this paper expresses the organs using Roman numerals (I -Liver, II -Gall bladder, } \\
\text { III - Heart, IV -Small intestine, V -Pancreas, VI -Stomach, VII-Lung, VIII-Large intestine, IX-Kidney, X-Urinary bladder). Zangs are given } \\
\text { odd numbers and belong to Yang while Fus are given even numbers and belong to Yin, where Yin and Yang are the contrary, yet } \\
\text { complementary forces that creates the harmony between the body and its environment according to Chinese philosophy (Chen, 2002). } \\
\text { In Oriental medicine, pairs of a Zang and a Fu are assigned to the five materials (I-II to wood, III-IV to fire, V-VI to earth, VII-VIII } \\
\text { to metal, and IX-X to water). In ECM as well, when the strength and weakness of Zangs and Fus are discussed, the strength of a } \\
\text { pair of corresponding Zang and Fu is dependent on each other. }\end{array}$} \\
\hline
\end{tabular}


factor in health is food. While most approaches to understanding the relation between health and diet seek a single ideal diet for all people, ECM claims there is no single, ideal dietary regimen, but rather that each of eight constitutions has specific foods that are beneficial or harmful to it. Thus not everyone will benefit from eating vegetarian, paleo, or any other diet; the appropriate diet that suits each person's constitution should be followed to optimize the individual's health condition by enhancing their immune function (See Table 2) ${ }^{5}$.

Several studies related to food therapy have been conducted. A previous study concluded that

Table 2. Food and regimen table

\begin{tabular}{|c|c|c|c|c|c|c|c|c|c|}
\hline & & Pulmotonia & Colonotonia & Pancreotonia & Gastrotonia & Hepatonia & Cholecystonia & Renotonia & Vesicotonia \\
\hline \multirow{6}{*}{$\begin{array}{c}\text { Recommended } \\
\text { Food }\end{array}$} & Shell, fish & $\begin{array}{c}\text { Sea shell and } \\
\text { fish }\end{array}$ & $\begin{array}{c}\text { Sea shell and } \\
\text { fish }\end{array}$ & $\begin{array}{c}\text { All kinds of } \\
\text { shell and fish, } \\
\text { globefish }\end{array}$ & $\begin{array}{c}\text { Sea shell and } \\
\text { fish, } \\
\text { globefish }\end{array}$ & Eel, loach & Eel, loach & & \\
\hline & Meat & & & Pork, beef & Pork & $\begin{array}{c}\text { All kinds of } \\
\text { meat, dairy } \\
\text { products }\end{array}$ & $\begin{array}{l}\text { Beef, pork, } \\
\text { dairy products }\end{array}$ & Chicken, beef & Chicken, beef \\
\hline & Vegetable & $\begin{array}{c}\text { Green } \\
\text { vegetable }\end{array}$ & $\begin{array}{c}\text { Green } \\
\text { vegetable }\end{array}$ & $\begin{array}{l}\text { All kinds of } \\
\text { vegetable }\end{array}$ & $\begin{array}{c}\text { Green } \\
\text { vegetable }\end{array}$ & $\begin{array}{c}\text { Root } \\
\text { vegetable, } \\
\text { garlic }\end{array}$ & $\begin{array}{l}\text { Root vegetable, } \\
\text { garlic }\end{array}$ & $\begin{array}{c}\text { Red pepper, } \\
\text { ginger, } \\
\text { Welsh onion }\end{array}$ & $\begin{array}{c}\text { Red pepper, } \\
\text { ginger, Welsh } \\
\text { onion }\end{array}$ \\
\hline & Fruit & $\begin{array}{l}\text { Banana, } \\
\text { strawberry, } \\
\text { peach, } \\
\text { cherry, } \\
\text { persimmon, } \\
\text { muskmelon, } \\
\text { Chinese } \\
\text { quince }\end{array}$ & $\begin{array}{c}\text { Strawberry, } \\
\text { peach, cherry, } \\
\text { persimmon, } \\
\text { grape, } \\
\text { pineapple }\end{array}$ & $\begin{array}{l}\text { Persimmon, } \\
\text { pear, } \\
\text { muskmelon, } \\
\text { watermelon, } \\
\text { melon, } \\
\text { strawberry, } \\
\text { banana }\end{array}$ & $\begin{array}{l}\text { Persimmon, } \\
\text { muskmelon, } \\
\text { watermelon, } \\
\text { pineapple, } \\
\text { grape, } \\
\text { strawberry, } \\
\text { banana }\end{array}$ & $\begin{array}{l}\text { Pear, apple, } \\
\text { watermelon, } \\
\text { nuts, } \\
\text { mushroom }\end{array}$ & $\begin{array}{c}\text { pear, melon, } \\
\text { nuts, mushroom }\end{array}$ & $\begin{array}{c}\text { Apple, } \\
\text { tangerine, } \\
\text { orange, } \\
\text { mango, } \\
\text { tomato }\end{array}$ & $\begin{array}{c}\text { Apple, } \\
\text { tangerine, } \\
\text { orange, } \\
\text { mango, } \\
\text { tomato }\end{array}$ \\
\hline & Vitamin & $\mathrm{E}$ & B & $\mathrm{E}$ & E & A,B,C,D & A,C,D,E & B & B \\
\hline & Others & Cocoa & Cocoa & & Cocoa & $\begin{array}{l}\text { Wheat flour, } \\
\text { coffee, } \\
\text { alkali drink }\end{array}$ & $\begin{array}{l}\text { Wheat flour, } \\
\text { coffee, } \\
\text { alkali drink }\end{array}$ & Acid drink & Acid drink \\
\hline \multirow{6}{*}{ Harmful food } & $\begin{array}{l}\text { Shell and } \\
\text { fish }\end{array}$ & $\begin{array}{l}\text { Freshwater } \\
\text { fish }\end{array}$ & $\begin{array}{l}\text { Freshwater } \\
\text { fish }\end{array}$ & & & $\begin{array}{c}\text { Sea shell and } \\
\text { fish }\end{array}$ & $\begin{array}{c}\text { Sea shell and } \\
\text { fish }\end{array}$ & $\begin{array}{l}\text { All kinds of } \\
\text { shell and fish }\end{array}$ & $\begin{array}{l}\text { All kinds of } \\
\text { shell and fish }\end{array}$ \\
\hline & Meat & $\begin{array}{c}\text { All kinds of } \\
\text { meat, dairy } \\
\text { products }\end{array}$ & $\begin{array}{l}\text { All kinds of } \\
\text { meat, dairy } \\
\text { products }\end{array}$ & Chicken & Chicken & & & Pork & Pork \\
\hline & Vegetable & $\begin{array}{l}\text { Red pepper, } \\
\text { garlic, root } \\
\text { vegetable, } \\
\text { mushroom }\end{array}$ & $\begin{array}{c}\text { Garlic, } \\
\text { root } \\
\text { vegetable, } \\
\text { mushroom }\end{array}$ & $\begin{array}{l}\text { Red pepper, } \\
\text { ginger, Welsh } \\
\text { onion }\end{array}$ & $\begin{array}{l}\text { Red pepper, } \\
\text { ginger, Welsh } \\
\text { onion }\end{array}$ & $\begin{array}{c}\text { Green } \\
\text { vegetable, } \\
\text { bracken }\end{array}$ & $\begin{array}{c}\text { Green } \\
\text { vegetable, } \\
\text { bracken }\end{array}$ & & \\
\hline & Fruit & $\begin{array}{l}\text { Apple, pear, } \\
\text { melon }\end{array}$ & $\begin{array}{l}\text { Apple, pear, } \\
\text { melon }\end{array}$ & $\begin{array}{l}\text { Apple, } \\
\text { tangerine, } \\
\text { orange, } \\
\text { mango, } \\
\text { tomato }\end{array}$ & $\begin{array}{c}\text { Apple, } \\
\text { tangerine, } \\
\text { orange, } \\
\text { mango, } \\
\text { tomato }\end{array}$ & $\begin{array}{l}\text { Persimmon, } \\
\text { Chinese } \\
\text { quince, } \\
\text { cherry, white } \\
\text { grape }\end{array}$ & $\begin{array}{l}\text { Persimmon, } \\
\text { Chinese quince, } \\
\text { cherry, white } \\
\text { grape }\end{array}$ & $\begin{array}{c}\text { Persimmon, } \\
\text { muskmelon, } \\
\text { banana, } \\
\text { strawberry, } \\
\text { pineapple }\end{array}$ & $\begin{array}{c}\text { Persimmon, } \\
\text { muskmelon, } \\
\text { banana, } \\
\text { strawberry, } \\
\text { white grape }\end{array}$ \\
\hline & Vitamin & A,B,C,D & A,C,D,E & B & B & E & B & E & $\mathrm{E}$ \\
\hline & Others & $\begin{array}{l}\text { Wheat flour, } \\
\text { alkali drink }\end{array}$ & $\begin{array}{l}\text { Wheat flour, } \\
\text { alkali drink }\end{array}$ & & & Cocoa & Cocoa & Barley & Barley \\
\hline
\end{tabular}


the intake of beneficial foods per constitutional type changes the serum components in a relatively beneficial direction ${ }^{7)}$. Another study classified 124 college women based on Kuon's constitution theory and collected information on their food preference as well as their health status using the Cornell Medical Index. The results indicated that Hepatonia tended to have higher serum $\operatorname{IgM}$ and free amino acid content than other constitutions ${ }^{8)}$. A cross-sectional study from 2006 reported that distinct food therapy per constitutions improved quality of life ${ }^{9)}$. Another cross-sectional study from 2008 studying the effect of three major nutrient intake levels on health indicators indicated that subjects in Hepatonia and Cholecystonia had significantly higher weight, height, BMI, protein, fat, yet lower carbohydrate than those of Pulmotonia and Colonotonia $^{10)}$. Kim et al. published a study on the relationship between constitutions and the prevalence of metabolic syndrome, which was higher in the Hepatotia and Cholecystonia than in other constitutions ${ }^{11)}$.

The question of whether the ideal human diet should be carnivorous or vegetarian has generated research arguing for either approach ${ }^{12-13)}$, but from the perspective of ECM the question depends on the individual's constitution type. ECM determines whether a carnivorous or vegetarian diet suits someone's constitution by examining the relative strength of the organs whose functions aid in digesting meat. Biliary excretion is necessary to digest meat. In ECM, the liver and gallbladder are opposite the lung and large intestine and are in an antagonistic relationship with them. As seen in Table 1, the person who must eat lots of meat is one born with a strong liver for bile production, because the liver and gallbladder play an important role in the consuming of meat, and the nutrients produced in the consumption process benefit the lung and large intestine. However, for a person with a weak liver, digestion of meat will be poor, and eating lots of meat may result in disease due to excessive release of bile. If that person has a strong lung and large intestine, the person should be vegetarian instead of carnivore because the vegetarian diet provides abundant nutrients that strengthen weak liver and gallbladder. Therefore, both Hepatonia with a strong liver and weak lung, and Cholecystonia with strong gallbladder and weak colon, should have a meat diet, whereas Pulmotonia with strong lung and weak liver and Colonotonia with strong colon and weak gallbladder should be vegetarian $^{13)}$.

Although several clinicians in Korea report great success using ECM in their own clinical practice, there has been little objective research to document its effectiveness. To our knowledge, no practical studies have documented the effect on health outcomes of following for many years a food regimen corresponding to ECM. Therefore, this study provides objective, third-party research and presents the results of preliminary analysis on the effect of following a constitutional food regimen on quality of life and health outcomes across different constitutions. Specifically, this study examined whether patients whose constitution should benefit from a diet that includes meat, and patients whose constitution should be harmed by a diet that includes meat, had health outcomes reflecting the benefits of their particular constitutional diet. We hypothesized that patients whose dietary habits aligned with their constitutional recommendations would have 
better health outcomes than people whose dietary habits did not align with their constitutional recommendations.

\section{Subject or Material and Method}

\section{Subjects and Design}

This descriptive, comparative study employed a convenience subject of 243 Germans who were examined for their constitutions in Essen University Hospital Traditional Chinese Medicine (TCM) Center in Germany. They were either patients who have visited or employees worked at the TCM center and we obtained informed consent from all participants before test.

\section{Procedure}

A skilled physician who had been practicing ECM for nearly 20 years made the diagnosis of constitution for the subjects using unique pulse patterns composed of the combination of pulse formations on both the left and right radial arteries (Figure 1) ${ }^{3)}$. The pulse diagnosis of ECM is somewhat different from the traditional pulse diagnosis in both position and method. With the ECM diagnosis, the physician grips the wrist of the patient with three fingers contacting the radial artery about 1 inch proximal to the radial process and presses down the radial artery until a pulse disappears. Then, the physician releases pressure from the radial artery and catches the first pulse bounce up. For accuracy, the physician confirmed the diagnosis for each patient over three times before making the diagnosis final.

\section{Outcome Measurements}

Before participants were diagnosed for constitution, they completed a 13-item diet questionnaire.
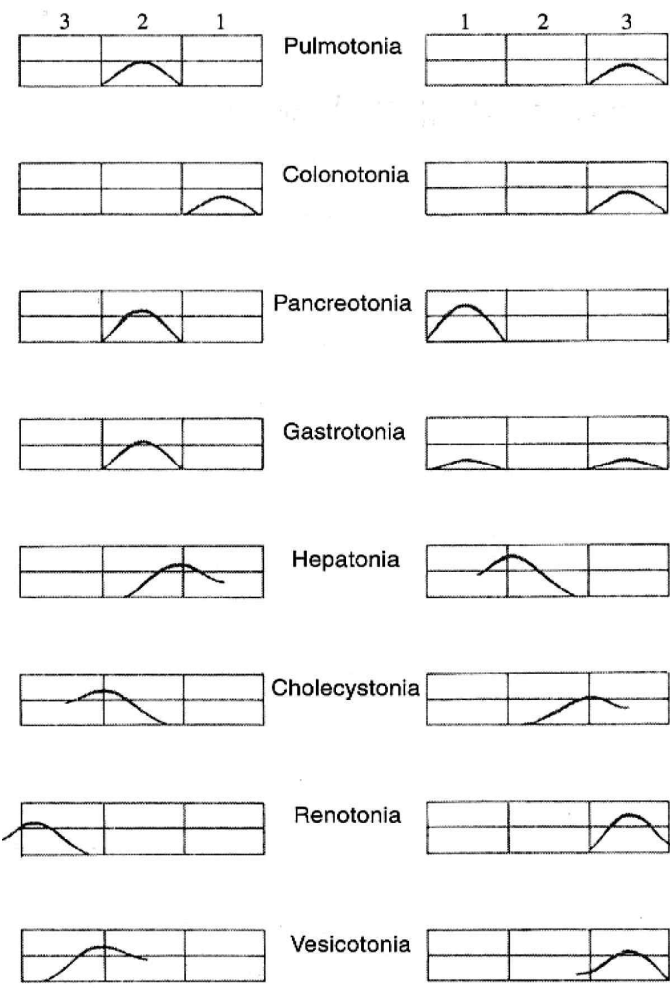

Renotonia

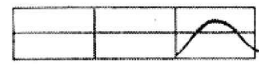

Vesicotonia

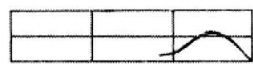

Fig. 1. Pulse Pattern according to constitutions in Eight Constitutional Medicine

The method of checking the eight-constitution pulse is as follows: First, ask the patient to lay down to check the pulses of the patient's right radial artery by using the doctor's left hand, and the patient's radial artery by using the doctor's right hand. When checking at the pulse, the position of the physician's 2nd, $3 \mathrm{rd}$, and 4 th finger are placed on the radial artery line that is about $5 \mathrm{~cm}$ below the styloid process of the radius. Next, the radial artery is pressed firmly enough so that the pulse can no longer be felt; then the strongest pulse is found by lowering the pressure applied to the artery. At this point, the three fingers should be pressed using the same pressure, taking into consideration the inclination of the radius.

LEFT: Left hand of the patient, RIGHT: Right hand of the patient (1) the index finger of the physician, (2) the middle finger of the physician, and (3) the ring finger of the physician.

The curved line indicates the first pulse wave increase; the box indicates the pulse strength.

Health outcomes were measured using the 36-item short form health survey (SF-36) questionnaire. The SF-36 is a set of items that can be used for a variety of purposes such as evaluating patient 
health outcomes and treatment effects on particular diseases in clinical studies. The items in SF-36 form eight subscales, scored between 0 and 100 , with 100 being the best score and 0 being the worst. The subscales are Physical Functioning (PF), Bodily Pain (BP), General Health Perception (GHP), Physical Role Functioning (PRF), Emotional Role Functioning (ERF), Vitality (V), Social Role Functioning (SF), and Mental Health (MH). The subscales can be used to form two summary measures: a Physical Component Score (PCS) and a Mental Component Score (MCS). The reliability and validity of SF-36 have been examined and established in numerous studies ${ }^{14)}$. A correlation between General Health and other scales in the SF-36 questionnaire score was found to be positive and greater than .30 , and no scoring error was detected.

\section{Statistical Analysis}

All data were entered and analyzed in IBM SPSS 22.0 ${ }^{15)}$. Descriptive statistics were computed to characterize the sample using frequency and percentage for categorical variables and mean with standard deviation for continuous variables. Two-way factorial Analyses of Variance (ANOVAs) were computed to test differences on the subscales of SF-36 for the constitutional types and the intake of meat. All statistical significances were reported at $p<.05$.

\section{Results}

\section{Subject characteristics}

Of the 243 subjects, one did not complete a questionnaire, leaving a total of 242 persons (a response rate of $99.6 \%$ ). The majority of
Table 3. Sample characteristics

\begin{tabular}{lr}
\hline Variables & $N(\%)$ \\
\hline Constitutions & \\
Pulmotonia & $19(7.9)$ \\
Colonotonia & $7(2.9)$ \\
Renotonia & $41(16.9)$ \\
Vesicotonia & $9(3.7)$ \\
Pancreotonia & $71(29.3)$ \\
Gastrotonia & $0(0.0)$ \\
Hepatonia & $66(27.3)$ \\
Cholecystonia & $29(12.0)$ \\
Constitutions for the current study & \\
Hepatonia and Cholecystonia & $95(39.3)$ \\
Pulmotonia and Colonotonia & $26(10.8)$ \\
\hline Gender & \\
Male & $29(24.0)$ \\
Female & $91(75.2)$ \\
\hline Meat Intake & \\
$\quad$ No & $22(18.2)$ \\
Yes & $98(81.0)$ \\
\hline Note. No attempts were made to replace the missing data so
\end{tabular}

participants were female $(\mathrm{n}=193 ; 79.8 \%)$ and the average age was 44.3 years old $(\mathrm{SD}=13.6)$. Most participants in our sample were diagnosed as Hepatonia, Pancreotonia, or Cholecystonia constitution types. With our focus in this study on dietary habits that either include or avoid meat, we included for analysis only those constitutions with specific recommendations about eating or avoiding meat: Hepatonia, Cholecystonia, Pulmotonia, and Colonotonia. We focused our analysis on two groups: those who benefit from eating meat (Hepatonia/Cholecystonia; $\mathrm{n}=95$ ) and those who are harmed by eating meat (Pulmotonia/ Colonotonia; $\mathrm{n}=26$ ). Sample characteristics are summarized in Table 3. The sample had relatively high meat consumption, and a higher percentage of those in Hepatonia/ Cholecystonia ( $\mathrm{n}=81 ; 85.3 \%$ ) consumed meat than those in Pulmotonia/Colonotonia ( $\mathrm{n}=17 ; 65.4 \%$ ). 


\section{Health outcome assessments for the 2 groups (Hepatonia/Cholecystonia vs. Pulmotonia/Colonotonia)}

Two-way factorial ANOVAs were used to compare subjects in Hepatonia/Cholecystonia and those in Pulmotonia/Colonotonia for the effect of meat-eating on their health outcomes, as measured by the SF-36 questionnaire. We hypothesized that health outcomes in Hepatonia/Cholecystonia would be good if they ate meat and those in Pulmotonia/Colonotonia would be bad if they ate meat. Results indicated that meat intake did not make significant differences in the health outcomes of SF-36 between the two groups (all $p$ values $>.05)$.

Our sample had a wide range in the length of time they had followed their dietary habits, from 0.5 and 60 years, with a median of 20 years. As one can assume that it takes time to get make dietary intake a habit, we analyzed only those who had followed their dietary habit more than 20 years further by re-running two-way factorial ANOVAs. Results indicated that subjects in Hepatonia/Cholecystonia had significantly better scores in general health, social functioning, mental health, emotional role functioning, and higher mental component scores than those in Pulmotonia/Colonotonia (See Table 4).

\section{Discussion}

This study intended to present a preliminary analysis of the effect of following constitutional food regimens on quality of life and health outcomes for different constitutions. Although we did not find significant differences in health outcomes between the two groups of Hepatonia/ Cholecystonia and Pulmotonia/Colonotonia, those with long-term dietary habits, the Hepatonia/ Cholecystonia subjects had several better health outcomes than the Pulmotonia/Colonotonia subjects. One thing to worthwhile to note is that a relatively large percentage $(65.4 \%)$ of Pulmotonia/ Colonotonia subjects consumed meat, while meat consumption could be possible to harmful for them.

Most studies addressing the effect of food on health conclude that one needs to have an adequate balance between the intake of meat and vegetable ensuring the protein is obtained from either meat or vegetable. However, constitutional medicine argues a different perspective in that constitutional type determines whether or not the intake of certain foods is beneficial. For example, it is common to hear being on a vegetarian diet actually results in suffering for those who are not fit for vegetarianism. On the other hand, in many cases various cancer symptoms have improved as a result of stopping a carnivorous diet and taking a vegetarian diet for those who are fit for vegetarianism. The ultimate idea is that whether to take meat or vegetable diets should be different from person to person per their constitutional type and people could benefit from balancing their food consumption according to the diagnosis of their constitutions.

In our sample, Hepatonia/Cholecystonia was the most frequent among the eight constitutions (total 39.3\%, 68.6\% if including Pancreotonia). However, an increasing number of people intend to consume more vegetables thinking eating vegetables are healthy without proper reason while it is only true if they are one of those constitutional types in which eating vegetables are beneficial for them. 
We argue that even a vegetarian diet can be associated with poorer health if one's constitution is not considered. One such example is an increase in obesity associated with a change in food policy in the U.S. Obesity has been one of the prevailing social problems and the U.S. began promoting low-fat diets in the mid-1970s as a way to deal with continuously

Table 4. Mean differences between constitution groups on SF-36 scores for those with more than 20 years on dietary habits

\begin{tabular}{|c|c|c|c|c|}
\hline Variables & $\begin{array}{c}\text { Hepatonia and } \\
\text { Cholecystonia } \\
(\mathrm{n}=35) \\
\text { Mean (SD) }\end{array}$ & $\begin{array}{c}\text { Pulmotonia and } \\
\text { Colonotonia } \\
(\mathrm{n}=13) \\
\text { Mean (SD) }\end{array}$ & $\mathrm{F}$ & $p$ \\
\hline Physical Functioning & $85.58(17.91)$ & $86.81(18.61)$ & & \\
\hline Constitution & & & 0.04 & .854 \\
\hline Meat Intake & & & 0.01 & .978 \\
\hline Constitution*Meat Intake & & & 0.56 & .457 \\
\hline Bodily Pain & $72.31(24.93)$ & $60.45(27.38)$ & & \\
\hline Constitution & & & 1.79 & .186 \\
\hline Meat Intake & & & 0.08 & .776 \\
\hline Constitution*Meat Intake & & & 0.01 & .961 \\
\hline General Health Perception & $67.81(15.99)$ & $53.07(22.30)$ & & \\
\hline Constitution & & & 9.31 & .003 \\
\hline Meat Intake & & & 0.01 & .971 \\
\hline Constitution*Meat Intake & & & 2.05 & .158 \\
\hline Physical Role Functioning & $80.28(31.05)$ & $77.27(36.14)$ & & \\
\hline Constitution & & & 0.13 & .726 \\
\hline Meat Intake & & & 3.43 & .069 \\
\hline Constitution*Meat Intake & & & 0.99 & .324 \\
\hline Emotional Role Functioning & $84.00(30.29)$ & $63.63(43.34)$ & & \\
\hline Constitution & & & 6.06 & .017 \\
\hline Meat Intake & & & 0.79 & .379 \\
\hline Constitution*Meat Intake & & & 3.87 & $\begin{array}{l}.054 \\
\ldots \cdots\end{array}$ \\
\hline Vitality & $54.46(18.50)$ & $56.36(22.37)$ & & \\
\hline Constitution & & & 0.34 & .560 \\
\hline Meat Intake & & & 0.01 & .975 \\
\hline Constitution*Meat Intake & & & 3.08 & .084 \\
\hline Social Role Functioning & $83.25(21.08)$ & $64.77(22.92)$ & & \\
\hline Constitution & & & 7.26 & .009 \\
\hline Meat Intake & & & 0.05 & .827 \\
\hline Constitution*Meat Intake & & & 0.72 & .399 \\
\hline Mental Health & $72.45(14.41)$ & $62.55(17.64)$ & & \\
\hline Constitution & & & 7.84 & .009 \\
\hline Meat Intake & & & 0.01 & .941 \\
\hline Constitution*Meat Intake & & & 3.33 & .073 \\
\hline Physical Component Score & $50.24(7.52)$ & $48.15(9.69)$ & & \\
\hline Constitution & & & 0.58 & .451 \\
\hline Meat Intake & & & 0.13 & .720 \\
\hline Constitution*Meat Intake & & & 0.09 & .769 \\
\hline Mental Component Score & $48.69(9.42)$ & 2.25 (12.49) & & \\
\hline Constitution & & & 6.78 & .012 \\
\hline Meat Intake & & & 0.10 & .761 \\
\hline Constitution*Meat Intake & & & 3.49 & .067 \\
\hline
\end{tabular}


increasing obesity ${ }^{16)}$. However, fat is mistakenly known to reduce the intake of other types of foods with a long-lasting satiety and reducing fat can result in obesity because it will lead to more intake of carbohydrate and low absorption of essential nutrients such as calcium, vitamins A, $\mathrm{D}, \mathrm{E}$, and $\mathrm{K}$. This is called that "the paradox of fat". In a German study, there has been a substantial increase in the prevalence of obesity and the increase in obesity is especially prominent among men and young adults ${ }^{17)}$. The increased intake of carbohydrates instead of fat is likely to be the cause of increased obesity, like in the U.S. Many Germans in our sample had constitutions that benefit from eating meat, and being a vegetarian for the sake of health should be considered cautiously.

Another thing to note is that education level of sample in this study was higher than the general population of Germans. More educated people tend to eat healthier in Germany, perhaps due to their attentiveness to the needs of their body. However, it is important to note that "healthy" eating does not always correlate with better health outcomes if not tailored to the individual. Rather, eating should improve one's health by stabilizing the immune system and generating more energy based on the food types that are right for their constitution.

While this study documents the effect of following a food regimen corresponding to ECM for a long time on health outcomes, our study has several limitations. First, we used a convenience sample of patients in a single medical center, so the results of this study may not be generalizable to the general German population. Second, the majority of this sample (about 80\%) were women, so a potential confounding association with gender could not be ruled out. Third, the meat intake was measured in a dichotomous manner (i.e. yes or no), so future studies should investigate the effect of meat intake in various amounts. Fourth, this study included a slightly fewer number of subjects than the required sample size per a priori power analysis $(n=128)$ computed for a factorial ANOVA using $\mathrm{G}^{*}$ power 3.1.9.2 ${ }^{18)}$, so it was potentially underpowered to detect group differences. Fifth, while it has many merits, the SF36 questionnaire does not seem to be the best questionnaire to check the health status of meat eating. The authors originally considered the use of health screening results such as cholesterol and liver function tests, but it was not possible to use other measurements such as blood test results as a dependent variable because Germans do not have these tests in their health checkup routine. In future studies, we believe that confirmation through lipid profiles (Total Cholesterol, HDL, LDL, TG) will help us better understand the impact of following the recommended diet for diagnosed constitutions. Sixth, due to the nature of ECM diagnosis, a physical diagnosis is made with a pulse, but in this study, only one clinician diagnosed a participant by a pulse diagnosis and did not cross-check. However, more than 20 years of experience in ECM have been verified and more than two diagnoses have been made for one participant to improve accuracy. Finally, while results show better health outcomes for the Hepatonia/Cholecystonia subjects than the Pulmotonia/Colonotonia subjects, it is not still clear whether such results were due to the relatively large meat consumption of Pulmotonia/ Colonotonia subjects and there are possibly 
many confounding variables that could have resulted in such outcome. Therefore, future studies should include such confounding variables in the analysis and evaluate in a more comprehensive manner.

Nonetheless, we believe this study sheds preliminary light on the need of establishing an objective assessment of ECM and the importance of choosing a diet according to individual constitution.

\section{Conclusions}

This study begins establishing an objective assessment of ECM and the possible value of choosing a diet according to individual constitution. Many Germans in our study belong to constitutions for which the consumption of meat can be beneficial, yet our results were inconclusive about the relationship between following constitutional food regimens and health outcomes. Better health can be acquired if people consume the right kind of foods per their constitutions. This study established initial groundwork for documenting the relations among individual constitution per ECM, constitutional diet, and health outcomes. Nonetheless, we believe more studies including clinical trials regarding this subject are needed.

\section{References}

1. Lee JM. Dong-Yi-Soo-Se-Bo-Won. Seoul, Korea: Jae Ma Lee, 1894

2. Chea H, Lyoo IK, Lee SJ, et al. An alternative way to individualized medicine psychological and physical traits of Sasang typology. J Altern Complement Med 2003
Aug;9(4):519-528.

3. Kuon D. A Study of Constitution-Acupuncture. J Int Congr Acupunct Moxibustion 1965; 10:149-167.

4. Kuon D. Studies on Constitution-Acupuncture Therapy. Chungang Uihak 1973;25(3):327342.

5. Kuon D. Studies on Constitution-Acupuncture Therapy. J Myong Ji Uni 1974;7:583-606.

6. Dowon Kuon. A Theoretical Basis for The Eight Constitution Acupuncture. Adv Med Biol 2010;5:243-245.

7. Kim SH, Kim WY, Lee PJ, Kuon DW, Kim YO. A Comparison of Nutritional Status Among Eight Constitutional Groups in Relation to Food Preference on the View Point of Constitutional Medicine. Korean J Nutr Soc 1985;18(2):155-166.

8. Kim K. A Study on nutrient Balance and Immune Response in Young Women affected by Dietary Proteins and Constitution [dissertation]. Seoul, Korea: Ewha Women University; 1986.

9. Chung H. The Effect of Constitutional Diet on View Point of Eight Constitutional Medicine [dissertation]. Seoul, Korea: Dongguk University; 2006.

10. Cho B. Effects of nutrient intakes on the blood biochemical parameters of the subjects classified by Eight Constitution [dissertation]. Pusan, Korea: Pusan National University; 2008.

11. Kim HJ, Jang BH, Kim MJ, Kim KC, Kuon WJ, Kim CK. Prevalence of and association between metabolic syndrome and the constitutions defined by Korean Eight Constitution Medicine. Medicine (Baltimore). 2020;99(7):e19074. 
12. Burkert NT, Muckenhauber J, Großschädl F, Rásky É, Freidl W. Nutrition and Health The Association between Eating Behavior and Various Health Parameters: A Matched Sample Study. PLoS One 2014;9(2): e88278.

13. Kuon D. Severe Patient and Vegetarian. Light and Salt 1994;5.

14. Burholt V, Bash P. Short Form 36 (SF-36) Health Survey Questionnaire: Normative Data for Wales. J Public Health 2011;33(4): 587-603.

15. IBM Corp. Released 2013. IBM SPSS Statistics for Windows, Version 22.0. Armonk, NY: IBM Corp.

16. National Health Department of Health and Human Services. Weight Status and Chronic Disease: Findings of New Hampshire Behavioral Risk Factor Surveillance Survey 2017. https://www.dhhs.nh.gov/dphs/cdpc/documents/ weight.pdf. Accessed November 13, 2018.
17. Mensink GB. Overweight and obesity in Germany: Results of the German Health Interview and Examination Survey for Adults (DEGS1). Bundesgesundheitsblatt Gesundheitsforschung Gesundheitsschutz 2013; 56(5-6):786-794. doi: 10.1007/s00103-012-1656-3.

18. Faul F, Erdfelder E, Lang A, Buchner A. G*Power 3: A flexible statistical power analysis program for the social, behavioral, and biomedical sciences. Behav Res Methods 2007;39:175-191.

\section{ORCID}

Changkeun Kim https://orcid.org/0000-0002-5764-737X

Dowon Kuon https://orcid.org/0000-0002-4541-4720

Myoungjin Kim https://orcid.org/0000-0002-7240-4683

Bo-Hyoung Jang https://orcid.org/0000-0002-2141-3483

Woojin Kim https://orcid.org/0000-0001-8494-4524 